\title{
Detection of Cytomegalovirus by ELISA Technique in Rheumatoid Arthritis Patients in Mosul / Iraq
}

\author{
MomammedA.Ibraheem, AnmarA.ALTaie*, Momammad A. Muhammad \\ Department of Biology, College of Science, University of Mosul, Iraq \\ *Corresponding author: anmaraltaee1978@yahoo.com
}

\begin{abstract}
In the present study, the association between CMV infection and rheumatoid arthritis was examined. A cohort of 92 serum samples were recruited from rheumatoid arthritis patients at age group of (30-62) years ( 25 males, 47 females) and 20 from healthy control. ELISA technique was used to assess the levels of CMV (IgM) and CMV (IgG) antibodies. Results showed that rheumatoid arthritis patients blood groups are as follow: $29.16 \%(\mathrm{AB}+), 25 \%(\mathrm{~A}+), 22.22 \%(\mathrm{O}+), 19.44 \%(\mathrm{~B}+), 1.39 \%(\mathrm{~A}-), 2.78 \%(\mathrm{~B}-)$, and $1.39 \%(\mathrm{AB}-)$, and $0 \%(\mathrm{O}-)$. According to gender the results showed the highest $\mathrm{ABO}$ blood groups in females with $\mathrm{AB}(20.83 \%)$, and $\mathrm{A}(19.44 \%)$ while blood group $\mathrm{O}^{-}$has been not recorded. The results of Rh phenotype tests in patients with rheumatoid arthritis were $\mathrm{Rh}^{+} 94.43 \%$ and $\mathrm{Rh}^{-} 5.56 \%$. CMV (IgG and IgM) assay using ELISA technique shows that 6 patients had seropostively of IgM against CMV antigen was apportioned as 2 patients with each blood groups $\mathrm{A}, \mathrm{B}$ and $\mathrm{AB}$ while the infection has not detected with blood group O. In addition CMV (IgG), revealed that 24 patients has seropositively, apportioned as $8(12.8 \mathrm{IU} / \mathrm{ml})$ at blood group $\mathrm{AB}, 6(11.1 \mathrm{IU} / \mathrm{ml})$ at blood group B , $6(10.2 \mathrm{IU} / \mathrm{ml})$ at blood groups A while in blood group $\mathrm{O}$ was $4(12.9 \mathrm{IU} / \mathrm{ml})$. According to sex , the results showed that highest titers of CMV IgG in females were 14 patients (14.3 $\mathrm{I} / \mathrm{ml})$ and in males 5 patients $(10.9 \mathrm{IU} / \mathrm{ml})$. The current study revealed no significant correlation between levels of IgG, IgM and CMV infections in rheumatoid arthritis patients. On other hand, there was weak significant correlation between blood groups and rheumatoid arthritis patients.
\end{abstract}

Key words: CMV, Rheumatoid arthritis, Blood groups,ELISA DOI : doi.org/10.46617/icbe6011

\section{Introduction}

Cytomegalovirus (CMV) is a member of the $\beta$-Herpesviridae family. It is the family's largest member $(150-200 \mathrm{~nm})$ and morphologically it can not be identified from other members. This pathogenic virus is widely distributed and can affect people of all ages (Arvin et al., 2007; Davison and Nair, 2004; Sever, 2002). The virus can affect the different organs of the body, lead to eye infections, gastrointestinal infections, hepatitis, and cytopenia. This often persists latently in cells and is distributed with blood products asymptomatically (Storch, 2000). General infection routes include horizontal family members transport, sexual transmission, intra-uterine vertical transmission, and breastfeeding. Infected blood products transfusion and contaminated organ transplantation are important sources of nosocomial human cytomegalovirus (HCMV) infection (Fowler \& Pass, 2006). Although anti-nuclear, anti-phospholipidandanti-CD13 autoantibodies are also common, autoantibodies evolve with HCMV infection, mainly against endothelial cells and smooth muscle cells. Emerging evidence suggests that 
HCMV may precede the onset of autoimmune disease and is likely to be more common among people with autoimmune predispositions (Nauclér, 2012, Shenk and Stinski, 2008).

A prevalence of CMV infection is high, with just a worldwide incidence of (30100) million (Al-Hakami et al., 2016; Asadi\&Ismailzadeh, 2005). Alwan et al., 2017 studied the prevalence of CMV in Iraqi Children. They revealed a prevalence of cytomegalovirus specific IgM as a serum marker was $5.4 \%$ among children under five years of age. Positive cytomegalovirus was associated with low socioeconomic status, maternal bad obstetric history, and lower age of children, while the infection was not associated to geographical distribution and gender. By stratified the children into symptomatic and asymptomatic according to the signs and symptoms of cytomegalovirus congenital and acquired infection at time of sample collection, $15 \%$ and $0.9 \%$ proved to have positive specific IgM among symptomatic and asymptomatic children, respectively. Jaundice was the most predominant clinical sign 56\% among symptomatic infected children, followed by hepatosplenomegaly $41.7 \%$.

ABO blood groups are one set of agglutinogens that are genetically determined carbohydrate molecules that are borne on the red blood cell surface membranes. ABO blood typing have shown some non-infectious and resistant interaction with various diseases. In most individuals in the blood group, the cells secrete the antigens and are involved in the blood circulation. It seems that a number of pathogens are vulnerable to non-secretors. The conceptual pathogenesis for this susceptibility is that as many pathogens that can bind cells and soluble antigens in the blood group to polysaccharide can inhibit this binding (Ahmed et al., 2004). There have been numerous reports over the past two decades that antigens in the blood group can serve as receptors for parasites, bacteria and viruses. As previous studies (Brown et al., 1994; Brown, et al., 1993) revealed, the $\mathrm{P}$ blood group antigen was the receptor for Parvovirus B19, a virus replicating only in progenitor erythroid cells. The researchers showed in another paper that individuals with the unusual phenotype were immune to infection with Parvovirus B19. The present investigation was conducted to determine the prevalence of anti-CMV in patients with rheumatoid arthritis and to determine if there is any association of blood groups with regard to CMV infections due to limited data concerning this relation.

\section{Materials and Methodsue}

\subsection{Sampling}

Seventy two blood samples were collected from patients with rheumatoid arthritis (25 males, 47females) and 20 from healthy control, who was admitted Al-Salam Teaching general hospital from April 2019 to September 2019. These subjects were diagnosed by the physicians and the diagnosis was confirmed by specific tests for this disease. Their ages are ranging from $30-64$ years. 


\subsection{Detection of $A B O$ blood groups and Rhesus factor}

The standard slide agglutination is performed using commercial antisera (Biotech laboratories Ltd, UK). Two drops of whole blood were placed in two different locations of a grease-free clean glass slide on which a few drops of antisera were added to blood group A and B. The blood cells are combined with the system stick and the antigen. The slide was then tilted and the result registered accordingly to agglutination assay (Barragan et al., 2000; Zoysa, 1985).

\subsection{Detection of CMV}

Cytomegalovirus (CMV) IgG and IgM enzyme immunoassay kits has been used to detect the presence of CMV infection (Biotech laboratories Ltd, UK), which provides a quantitative in vitro assay for human anti-bodies of $\mathrm{IgG}$ and $\operatorname{IgM}$ class against CMV in serum or plasma. In brief, the first reaction steps, diluted patient samples are incubated for 30 minutes in wells then wash 5 times used $300 \mu$ of working wash buffer and empty the wells. Specific IgG and IgM antibodies bind to antigens in the case of positive samples. A second incubation was performed to detect the bound antibodies after introducing conjugate enzyme (HRP) into each well, after wash added $100 \mu$ of substratum into microplate wells and incubated in dark at $37^{\circ} \mathrm{c}$ for 15 minutes, then finally stopped the reaction by acid and read the absorption at $450 \mathrm{~nm}$ with a microwell reader within 15 minutes.

\subsection{Statistical analysis}

Statistical analysis was performed using SPSS 15.0 software (SPSSFW; SPSS Inc). A chi-square test is use for investigating the correlation between categorical variables. Qualitative variables are given as percentages and a value of $\mathrm{p}<0.05$ was considered significant.

\section{Results}

The distribution of the blood groups of patients with rheumatoid arthritis were $29.16 \% \mathrm{AB}^{+}, 25 \% \mathrm{~A}^{+}, 22.22 \% \mathrm{O}^{+}, 19.44 \% \mathrm{~B}^{+}, 1.39 \% \mathrm{~A}^{-}, 2.78 \% \mathrm{~B}^{-}$and $1.39 \% \mathrm{AB}^{-}$

while blood group $\mathrm{O}^{-}$has been not recorded. The results of $\mathrm{Rh}$ phenotype tests in the rheumatoid arthritis patients were $\mathrm{Rh}^{+} 94.43 \%$ and $\mathrm{Rh}^{-5} 5.56 \%$. On other hand, according to gender the results revealed the highest $\mathrm{ABO}$ blood groups in females withAB and $\mathrm{A}$ were $20.83 \%, 19.44 \%$ respectively while in males with group B and O were $9.72 \%$ and $8.33 \%$ respectively (Table 1 ). 
Table 1: Distribution of $\mathrm{ABO}$ blood group and Rhesus factor in $\mathrm{Rh}$ patients of both sexes (Numbers and Percentage in parentheses).

\begin{tabular}{|c|c|c|c|c|}
\hline \multirow{2}{*}{ ABO blood groups } & \multirow[t]{2}{*}{ Sex } & $\begin{array}{c}\mathrm{Rh} \\
\text { positive }\end{array}$ & Rh negative & Total \\
\hline & & \multicolumn{3}{|c|}{ No. $(\%)$} \\
\hline \multirow{2}{*}{ A } & M & $4(5.56)$ & $1(1.39)$ & \multirow{2}{*}{$19(26.39)$} \\
\hline & $\mathrm{F}$ & $14(19.44)$ & - & \\
\hline \multirow{2}{*}{ B } & M & $7(9.72)$ & $1(1.39)$ & \multirow{2}{*}{$16(22.22)$} \\
\hline & $\mathrm{F}$ & $7(9.72)$ & $1(1.39)$ & \\
\hline \multirow{2}{*}{ ABnd } & M & $5(6.94)$ & $1(1.39)$ & \multirow{2}{*}{$21(29.16)$} \\
\hline & $\mathrm{F}$ & $15(20.83)$ & - & \\
\hline \multirow{2}{*}{$\mathbf{O}$} & M & $6(8.33)$ & - & \multirow{2}{*}{$16(22.22)$} \\
\hline & $\mathrm{F}$ & $22(30.55)$ & - & \\
\hline \multirow{2}{*}{ Total } & M & $10(13.89)$ & $3(4.17)$ & \multirow{2}{*}{$72(100)$} \\
\hline & $\mathrm{F}$ & $46(63.88)$ & $1(1.39)$ & \\
\hline
\end{tabular}

The results showed 6 patients had seropostively of IgM against CMV antigen. The CMV infection was recorded with blood groups $\mathrm{A}, \mathrm{B}$ and $\mathrm{AB}$ not showed with group $\mathrm{O}$. Positivity of IgM antibodies against CMV dose not show significant relationships with gender $(\mathrm{p}>0.05)$ see Table 2 .

Table2: Numbers of CMV (IgM) in relation of ABO blood groups and in both sex.

\begin{tabular}{|c|c|c|c|c|c|}
\hline \multirow{2}{*}{ Blood groups } & A & B & AB & O & Total \\
\cline { 2 - 6 } Gender & \multicolumn{5}{|c|}{ No.(Total cases) } \\
\hline Males & $0(5)$ & $1(8)$ & $1(6)$ & $0(6)$ & $2(25)$ \\
\hline Females & $2(14)$ & $1(8)$ & $1(15)$ & $0(10)$ & $4(47)$ \\
\hline Controls & $0(5)$ & $0(5)$ & $0(5)$ & $0(5)$ & $0(20)$ \\
\hline Total & $2(19)$ & $2(16)$ & $2(21)$ & $0(16)$ & $6(92)$ \\
\hline
\end{tabular}

Table 3 showed the titer of anti-CMV IgG antibodies in relation with blood groups and sex, the study showed that highest titers of CMV IgG in females were14persons (14.3 $\mathrm{I} / \mathrm{ml})$ and in males 5 persons $(10.9 \mathrm{IU} / \mathrm{ml})$ while 5 healthy person (controls) without rheumatoid arthritis was indicated (7.1 IU/ml)asin (Table 3). 
Table 3: Seropositively of CMV (IgG) in relation of ABO blood groups and gender

\begin{tabular}{|c|c|c|c|c|c|c|c|c|c|c|}
\hline \multirow{2}{*}{$\begin{array}{c}\text { Blood } \\
\text { grqups }\end{array}$} & \multicolumn{2}{|c|}{ A } & \multicolumn{2}{c|}{ B } & \multicolumn{2}{c|}{ AB } & \multicolumn{2}{c|}{ O } & \multicolumn{2}{c|}{ Total } \\
\cline { 2 - 11 } Gender & No.(\%) & Mean & No.(\%) & Mean & No.(\%) & Mean & No.(\%) & Mean & No.(\%) & Mean \\
$(\mathrm{IU} / \mathrm{ml})$ & & $(\mathrm{IU} / \mathrm{ml})$ & & $(\mathrm{IU} / \mathrm{ml})$ & & \\
\hline Males & $1(1.09)$ & 8.6 & $2(2.17)$ & 11.2 & $2(2.17)$ & 12.4 & 0 & 0 & $5(5.43)$ & 10.9 \\
\hline Females & $3(3.26)$ & 14.7 & $3(3.26)$ & 13.4 & $4(4.35)$ & 16.1 & $4(4.35)$ & 12.9 & $14(15.22)$ & 14.3 \\
\hline Controls & $2(2.17)$ & 6.3 & $1(1.09)$ & 7.6 & $2(2.17)$ & 6.9 & 0 & 0 & $5(5.43)$ & 7.1 \\
\hline Total & $6(6.522)$ & 10.2 & $6(6.522)$ & 11.1 & $8(8.69)$ & 12.8 & $4(4.35)$ & 12.9 & $24(26.08)$ & 10.9 \\
\hline
\end{tabular}

\section{Discussions}

The previous study of frequency $\mathrm{ABO}$ blood groups in rheumatoid arthritis patients showed that the blood group A is $42.22 \%$, B $20.54 \%$, O 30.10\%, AB 7.13\% (Stoia et al., 1967 ) While the blood group $\mathrm{A}$ is $49.10 \%$, B $14.80 \%$, O28.90\%, AB $7.20 \%$ (Çildağ et al., 2017) which did not acceptable with our study. However, there is no study from the Iraqi population or everywhere in the region showing blood group types frequency in patients with rheumatoid arthritis..

Several studies have shown an interaction, for example in RA or SLE, between the acquired immune responses to HCMV and the appearance of other autoimmune diseases. Precisely, the immunopathogenic mechanism by which HCMV can contribute to the course of autoimmune disease, such as molecular mimicry (UL83/ppp65) in patients with SLE in addition to joint inflammation by induction and expansion (CD4+/CD28- T-cells) in patients with HCMV infected with RA (Muhsin,2019; Halenius and Henge, 2014) .Analysis of 92 blood samples (patients and controls) showed that $24(26.1 \%)$ and 68 (73.9\%) anti-CMV IgG are positive. Only in six cases (6.52 percent) anti-CMV IgM antibody is confirm to be positive. In addition, 26.1 percent of subjects are positive for anti-CMV IgG antibody titers, indicating previous interaction with the virus and widespread disease distribution in the studied population. There was usually little evidence to support HCMV's role in arthritis pathogenesis. The peripheral blood identified low amounts of HCMV DNA (Çildağ et al., 2017; Alvarez et al., 2005) and adult joints with rheumatoid arthritis (Mousavi et al., 1998). The etiological significance of these findings is uncertain. The literature reporting HCMV infection is even more common in pediatric rheumatic diseases than it is in adult patients. In a non-quantitative PCR test (Dag et al., 2015; Tsai et al., 1995), The prevalence of HCMV DNA was found to be similar to controls in leukocytes obtained from children with SLE and JIA (Çildağ et al., 2017). 
The biological function of blood groups is associated with the presence of chemical moieties on the other cells that were originally defined as red cell antigens. They act as receptors and ligands against bacteria, parasites, and viruses. Anti-Aandanti-B are not $\mathrm{RBC}$ antibodies, but RBC-interacting bacterial antibodies. Individuals with $\mathrm{A}$ or $\mathrm{B}$ antigens make either Anti-A orAnti-B at about 3-6 months of age as they produce their own bacterial utero antibodies (Ewald and Sumner, 2016; Ahmed et al., 2004). The present study found that there was no significant difference in controls and patients with rheumatoid arthritis from the Mosul of Iraq in ABO and Rh classes. On the other hand, there are many studies associating various infections with specific blood group $\mathrm{ABO}$, like type $\mathrm{O}$ "non-secretors" have about twice the incidence of duodenal ulcer relative to type A and type B secretors. Type A, on the other hand, has a higher incidence of relative tumors of salivary gland, stomach and pancreas with blood type $\mathrm{O}$ groups (Choo et al., 1998). Plasmodium vivax is similarly protected from infection by people who lack Duffy system antigen (Ewald and Sumner, 2016; Ahmed et al., 2004). Another study showed a risk factor for duodenal ulcer in the blood group O. Blood group B has the highest rate of type II diabetes, because diabetes is prevalent in our population, people with high-risk group B should have early diabetes screening (Pasha et al., 2009).

\section{Conclusions}

There may be a greater problem with CMV infection than is generally recognized and reported. Although existing CMV infection treatment methods are not highly effective or available globally. As a summary, in our clinic, which is in a Mosul town, we observed no association between $\mathrm{ABO}$ or Rhesus (D) blood groups and rheumatoid arthritis. Nonetheless, more studies with larger series and at different sites, including molecular investigations, may be useful in determining the relationship between blood groups of $\mathrm{ABO}$ or Rhesus (D) and rheumatoid arthritis.

\section{References}

1. Sever, J.L. (2002). Pediatric cytomegalovirus infections. Clin Applied immunol., 3:47-49.

2. Storch, G.A.(2000). Essentials of Diagnostic virology. New York: Churchill Livingstone Co. pp: 203218.

3. Fowler, K.B. and Pass, R.F. (2006). Risk factors for congenital cytomegalovirus infection in the offspring of young women: exposure to young children and recent onset of sexual activity. Pediatrics, 118(2):e286-92.

4. Nauclér, C.S. (2012). Autoimmunity induced by human cytomegalovirus in patients with systemic lupus erythematosus. Arthritis Research \& Therapy, 14:101

5. Asadi, M.H. and Ismailzadeh, A. (2005). Prevalence of anti-CMV IgG and $\operatorname{IgM}$ antibodies in blood donors in Zanjan province, 2004. Journal of Zanjan University of Medical Sciences, 3(52):4348.

6. Ahmad, J.; Taj, A.S.; Rahim, A.; Shah, A. and Rehman, M. (2004). Frequency of Hepatitis B and Hepatitis $\mathrm{C}$ in healthy blood donors of NWFP: a single center experience. Journal Postgraduate Medical Institute 18(2) 343-52.

7. Brown, K.E.; Hibbs, J.R.; Gallinella, G.; Anderson, S.M.; Lehman, E.D.; McCarthy, P. and Young, W.S. (1994). Resistance to parvovirus B19 infection due to lack of virus receptor (erythrocyte P antigen). N Eng J Med., 330:1192-6.

8. Brown, K.E; Anderson, S.M and Young, N.S. (1993). Erythrocyte P antigen: cellular receptor for B19 Parvovirus. Science.262:114-17. 
9. Barragan, A; Kremsner, P.G; Wahlgren, M. and Carlson, J. (2000). Blood group A antigen is a coreceptor in Plasmodium falciparum rosetting. Infect Immun, 68:2971-2975.

10. Zoysa, D. (1985). The distribution of ABO and Rhesus (Rh) blood groups in Sri Lanka. Ceylon medical journal, 30:37-41.

11. Stoia, I.; Ramneantu, R. and Poitas, M. (1967). Blood groups abo and Rh (D) factor in the rheumatic diseases. Ann. rheum. Dis., 26: 332-333.

12. Alvarez-Lafuente R, Fernández-Gutiérrez B, de Miguel S, Jover JA, Rollin R, Loza E, Clemente D, Lamas JR: Potential relationship between herpes viruses and rheumatoid arthritis: analysis with quantitative real time polymerase chain reaction. Ann Rheum Dis2005, 64(9):1357-9.

13. Mousavi-Jazi, M.; Boström, L.; Lövmark, C.; Linde, A.; Brytting, M. and Sundqvist, VA. (1998). Infrequent detection of cytomegalovirus and Epstein-Barr virus DNA in synovial membrane of patients with rheumatoid arthritis. J Rheumatol, 25(4):623-628.

14. Tsai, Y.T.; Chiang, B.L.; Kao, Y.F. and Hsieh, K.H. (1995). Detection of Epstein-Barr virus and cytomegalovirus genome in white blood cells from patients with juvenile rheumatoid arthritis and childhood systemic lupus erythematosus. Int Arch Allergy Immunol., 106(3):235-240.

15. Choo Q-L, Kuo G, Weiner AJ (1998). Isolation of a DNA clone derived from a blood borne non A, non B viral hepatitis genome. Science 244(3) 362-4.

16. Pasha, A.K.;Hashir, M.M. andKhawar, S. (2009). Frequency of ABO blood group among medical students. Journal of Surgery Pakistan; 14(2): 93-95.

17. Lewkonia. R. M. and Ronald, F. (1969). ABO Blood Group Distribution in Serum Hepatitis. British Medical Journal, 3: 268-269.

18. Al-heti, N. M. A. (2002). Study of Haematological Changes in Patients with Neonatal Jaundice and Factors that affect its Occurrence in Al-Anbar Governorate. A thesis submitted to council of the science collage - Al-Anbar university in partial fulfillment for the degree of master in science.

19. Jeremiah, Z. A.; Koate, B.; Buseri, F. and Emelike, F. (2008). Prevalence of antibodies to hepatitis C virus in apparently healthy Port Harcourt blood donors and association with blood groups and other risk indicators. Blood Transfuse, 6(3):150-155.

20. Borén, T.; Falk, P.; Roth, K.A; Larson, G. and Normark, S. (1993) Attachment of helicobacter pylori to human gastric epithelium mediated by blood group antigens. Science. 62:1892-1825.

21. Westergren A. (1926). The technique of the red cell sedimentation reaction. Am Rev Tuberc.14: 94 101.

22. Alaoddoleheo,H., Sadighian,F., and Shahandeh,Z. The Study of ABO Groups and Rh factor in Active and Non-active Carriers of Hepatitis B Virus. J. Hepatitis Menthly, 2007; 7(1): 43-44.

23. Çildağ, S., Kara, Y. and Şentürk, T., 2017. ABO blood groups and rheumatic diseases. European journal of rheumatology, 4(4), p.250.

24. Dag, M.S., Turkbeyler, I.H., Ozturk, Z.A., Kısacık, B., Tutar, E. and Kadayıfçı, A., 2015. Cytomegalovirus ileocolitis in a rheumatoid arthritis patient: case report and literature review. Reumatismo, pp.13-16.

25. Ewald, D.R. and Sumner, S.C., 2016. Blood type biochemistry and human disease. Wiley Interdisciplinary Reviews: Systems Biology and Medicine, 8(6), pp.517-535.

26. Halenius, A. and Hengel, H., 2014. Human cytomegalovirus and autoimmune disease. BioMed research international, 2014.

27. Muhsin, J.M., 2019. Study the possible Seropositivity connection of EBV, Rubella Virus \& CMV infection with four groups of autoimmune diseases in sample of Iraqi patients. Al-Nisour Journal for Medical Sciences, 1(1), pp.108-117.

28. Arvin, A., Campadelli-Fiume, G., Mocarski, E., Moore, P.S., Roizman, B., Whitley, R. and Yamanishi, K. (2007). Human Herpesviruses: biology, therapy, and immunoprophylaxis. Cambridge University Press.pp.165-184.

29. Davison, F. and Nair, V., (2004). Marek's disease: an evolving problem. Academic Press.pp.86-97.

30. Al-Hakami, A.M., Shati, A.A., Alsuheel, A.M., Hakami, A.R., Al-Qahtani, M.A., Jelban, H.M. and Ali, A.S. (2016). Seroprevalence of human Cytomegalovirus antibodies among children with type I diabetes mellitus in the Aseer Region, Southwest KSA. Journal of Taibah University Medical Sciences, 11(4):388-394.

31. Shenk, T. and Stinski, M.F. (2008). Human Cytomegalovirus, Berlin, Springer,pp. 297-314.

32. Alwan et al., 2017. Prevalence of Cytomegalovirus in Iraqi Children. International Journal of Medical Research \& Health Sciences, 2017, 6(11): 113-124 